\title{
Erratum: Sex differences in the corpus callosum in preschool-aged children with autism spectrum disorder
}

Christine Wu Nordahl $1^{1,2^{*}}$, Ana-Maria losif ${ }^{1,3}$, Gregory S Young ${ }^{1,2}$, Lee Michael Perry ${ }^{4}$, Robert Dougherty ${ }^{5}$, Aaron Lee ${ }^{1,2}$, Deana Li ${ }^{1,2}$, Michael H Buonocore ${ }^{6^{\wedge}}$, Tony Simon ${ }^{1,2}$, Sally Rogers ${ }^{1,2}$, Brian Wandell ${ }^{4}$ and David G Amaral ${ }^{1,2}$

\section{Erratum}

Due to a publisher error, this article [1] was originally published with figures one and two interchanged. This error has now been corrected.

\section{Author details}

${ }^{1}$ The MIND Institute, School of Medicine, University of California at Davis, 2805 50th Street, Sacramento 95817, California, USA. ${ }^{2}$ Department of Psychiatry and Behavioral Sciences, School of Medicine, University of California at Davis, Sacramento 95817, California, USA. ${ }^{3}$ Department of Public Health Sciences, School of Medicine, University of California at Davis, Davis 95616, California, USA. ${ }^{4}$ Department of Psychology, Stanford University, Stanford 94305, California, USA. ${ }^{5}$ Center for Cognitive and Neurobiological Imaging, Stanford University, Stanford 94305, California, USA. ${ }^{6}$ Department of Radiology, School of Medicine, University of California at Davis, Sacramento 95817, California, USA.

Received: 28 May 2015 Accepted: 28 May 2015

Published online: 20 June 2015

\section{Reference}

1. Nordahl CW, losif AM, Young GS, Perry LM, Dougherty R, Lee A, et al. Sex differences in the corpus callosum in preschool-aged children with autism spectrum disorder. Molecular Autism. 2015;6:26.

\footnotetext{
* Correspondence: crswu@ucdavis.edu

${ }^{1}$ The MIND Institute, School of Medicine, University of California at Davis, 2805 50th Street, Sacramento 95817, California, USA

${ }^{2}$ Department of Psychiatry and Behavioral Sciences, School of Medicine,

University of California at Davis, Sacramento 95817, California, USA

Full list of author information is available at the end of the article

Submit your next manuscript to BioMed Central and take full advantage of:

- Convenient online submission

- Thorough peer review

- No space constraints or color figure charges

- Immediate publication on acceptance

- Inclusion in PubMed, CAS, Scopus and Google Scholar

- Research which is freely available for redistribution

Submit your manuscript at www.biomedcentral.com/submit 